\title{
TET1 wt Allele
}

National Cancer Institute

\section{Source}

National Cancer Institute. TET1 wt Allele. NCI Thesaurus. Code C95424.

Human TET 1 wild-type allele is located in the vicinity of 10q21 and is approximately 134 $\mathrm{kb}$ in length. This allele, which encodes methylcytosine dioxygenase TET 1 protein, plays a role in the modulation of DNA methylation. A translocation $\mathrm{t}(10 ; 11)(\mathrm{q} 22 ; \mathrm{q} 23)$ with $\mathrm{MLL}$ is associated with acute leukemia. 